\title{
BIOGEOCHEMISTRY OF LATE CRETACEOUS RUDIST BIVALVES: PALEOECOLOGIC AND PALEOCLIMATIC IMPLICATIONS
}

STEUBER, Thomas, Universität zu Köln, Geologisches Institut, Zülpicher Str. 49, 50674 Köln, Germany

During late Cretaceous times, rudist bivalves dominated over coral-algal-hydrozoan communities in most shallow Tethyan environments. Morphogenetic modifications of hinge and ligament resulted in complete uncoiling of both valves. This translation of shell accretion to vertical growth was an important adaptation for successful competition with other sessile epibenthic suspension feeders.

The isotopic and elemental compositions of rudist shells provide data about growth rates, individual life histories and Cretaceous paleoclimate. Numerous shells from various depositional settings of the Eastern Mediterranean and Arabia were investigated in sclerochronological sections. The outer shell layer originally consisted of relatively stable low-Mg calcite. Preservation of fibrous prismatic ultrastructures, and concentrations of $\mathrm{Fe}, \mathrm{Mn}, \mathrm{Sr}$, and $\mathrm{Mg}$ that are similar to those of extant bivalve shells indicate the absence of severe diagenetic alterations of geochemical records in the analyzed rudist shells.

A distinct cyclicity of $\delta 180$ is generally observed in sclerochronological stable-isotope profiles of outer shell layers. It is ascribed to seasonal temperature variations and, consequently, indicates annual growth increments. These cycles frequently correspond to growth bands or sculptural elements such as shell lamellae. Vertical growth rates were less than $10 \mathrm{~mm} / \mathrm{yr}$ in shells from lagoonal environments with low sediment supply, and amounted to $50 \mathrm{~mm} / \mathrm{yr}$ in specimens that lived on rapidly accumulating sediments of nearshore siliciclastic settings, or on unstable substratums of seaward slopes of rudist banks. One of the investigated specimens maintained annual vertical shell accretion of $40-50 \mathrm{~mm}$ during eight successive years of growth. Geniculate morphotypes resulted when vertical growth exceeded sedimentation rates. Without stabilization by continuously accumulated sediment and in absence of binding organisms, the shells eventually toppled and allometric growth subsequently lifted the commissure above the sediment surface. $\mathrm{CaCO}_{3}$ production of rudist pseudocolonies was in the range of 5 to $20 \mathrm{~kg} \cdot \mathrm{m}^{-2} \cdot \mathrm{yr}^{-1}$, as estimated from the observed growth rates. This is similar to the productivity of modern coral reefs. In contrast to coral-algal-hydrozoan communities, high rates of $\mathrm{CaCO}_{3}$ precipitation by rudists also occurred in siliciclastic settings.

$\mathrm{Mg}$ concentrations in outer shell layers are in the range of 800 to $3000 \mathrm{ppm}$, and are generally covariant with $18 \mathrm{O}$-contents. Similar to extant bivalves, $\mathrm{Mg}$ was apparently incorporated preferentially during periods of high ambient water temperature. Sr concentrations are rather constant in individual shells and vary between 1000 and $1600 \mathrm{ppm}$. Fe and Mn contents are frequently below 100 and $10 \mathrm{ppm}$, respectively, but show cyclic distributions that are covariant with those of $18 \mathrm{O}$ and $\mathrm{Mg}$ in some shells.

It is tempting to relate the oxygen isotopic compositions of the shells to Cretaceous paleotemperatures. In most analyzed shells, isotopic temperatures are in the range of 26 to $35^{\circ} \mathrm{C}$, which seems reasonable considering a paleogeographic setting of 20-30 ${ }^{\circ} \mathrm{N}$. However, paleoclimatic interpretations are complicated by several uncertainties. First, the isotopic composition of nearshore sea water probably was not constant due to seasonally enhanced evaporation or periodical mixing with freshwater. Second, the isotopic records of the shells might be incomplete, as shell accretion could have ceased during times of unfavourable environmental conditions or periods of spawing. Finally, although extant bivalves are among the most faithful isotopic recorders of environmental changes such as temperature or salinity, isotopic disequilibrium during $\mathrm{CaCO}_{3}$ preciptation by rudists cannot be ruled out. In fact, kinetic isotope effects are indicated by covariant, low contents of $18 \mathrm{O}$ and ${ }^{13} \mathrm{C}$ as well as high $\mathrm{Mg}$ concentrations in several shells of Torreites. In these specimens, the amplitudes of isotopic paleotemperatures are unreasonably high in fast-growing juvenile shells, and gradually decrease during ontogeny. Disequilibrium precipitation in other rudists is revealed by a critical evaluation of sclerochronological stable-isotope and minor-element records. This supports the hypothesis of photosymbiosis, at least in some rudist genera. Consequently, paleoclimatic conclusions require careful investigations of numerous shells from well-defined paleoenvironmental settings. 